\title{
Effects of Communication and Characteristics in Pekka Groups on the Economic Empowerment of Members
}

\author{
Ana Kuswanti ${ }^{1}$, Amiruddin Saleh ${ }^{1}$, Aida Vitayala S. Hubeis ${ }^{1}$, Herien Puspitawati ${ }^{2}$ \\ ${ }^{1}$ Agricultural and Rural Development Communication Study Program, Faculty of \\ Human Ecology, IPB University, Jl. Raya Darmaga, Bogor, West Java 16680, Indonesia \\ ${ }^{2}$ Departement of Family and Consumer Science, Faculty of Human Ecology, IPB \\ University, Jl. Raya Darmaga, Bogor, West Java 16680, Indonesia \\ *Correspoding author, e-mail: anakuswanti@upnvj.ac.id
}

\begin{abstract}
The study was conducted in Batang Regency, Central Java. Still high levels of family poverty in this area, especially the condition of the family head women and tend to have nonpermanent work, make the authors interested in doing this in-property research. Research methods using quantitative mixed methods are strengthened by qualitative analysis. The sampling technique uses stratified random sampling, using the Slovin formula to determine the magnitude of the number of respondents. The study population numbered 535, with a total sample of research were 229 female heads of households. The results showed that indicators of group roles and companion roles had a very large contribution in encouraging the characteristics of women's household heads to be more empowered. Through a companion role, making a family of female heads more actively communicating. Through the development of public speaking, establishing a critical culture in the group, thus growing self-confidence, forming a empowered, independent, and potential self. Important research is conducted to see the extent to which the women's head program has walked the trunk, creating many tough women. Research novelty was obtained based on a combination of group communication attributed to economic empowerment.
\end{abstract}

Keywords: Economic Empowerment, Group Characteristics, Effects of Communication. Female Head of Family.

\section{Introduction}

Women's development is an urgency and an integral part of national development and development programs in alleviating poverty. (Hubeis, 2010) states that it is time for women to participate in the development. However, society considers naturally that women are still required that all work is carried out independently and alone by women. According to Law of the Republic of Indonesia number 1 of 2017 concerning gender equality, and in line with the National Medium-Term Development Plan (RPJMN) III (2015-2019) as explained for the priority of human resource development (HRD), directed towards improving the quality of human resources, one of which marked by increasing gender equality and empowering women (Bappenas, 2013). The development of gender equality in Indonesia has shown very good development, although many improvements must be made. Empowering women is an important step to achieving equality. By empowering herself, women can open and enjoy access to the widest possible development and can even have a positive social and economic impact on the surrounding environment. Women are a development asset that has enormous potential when they are in a conducive environment and conditions (PIPEL \& LAN, 2018).

As discussions on women's empowerment increase, this also offers potential empowerment for women. One of the newest strands is that, social relations will renew 
feminist politics, that is, women will have the power to play a role in many fields including politics (Kabeer, 2010; Baer H, 2016). The strand that appears In this case how do women pay attention and actively participate in the digital space and know how to deal with power structures with contributions online activities (Hasinoff, 2014; Portwood, 2014).

The program in households headed by women began in December 2001 with a vision to empower households headed by women to help create a prosperous, genderjust, and dignified society. So that it can realize the Pekka's mission namely to regulate and facilitate the households headed by women to be able to improve welfare in their lives, have access to various resources, be able to actively participate in every development cycle in their area, have a critical awareness of their rights as human beings and citizens, and have control over themselves and process decision-making both within the family and in the community. The Pekka program initiated by the National Women's Commission has four organizing pillars, including: (1) building critical awareness of human rights, (2) increasing capacity, (3) developing organizations and networks, and (4) advocating for change (Seknas Pekka, 2014).

Women's participation in various sectors will emphasize factors in the process of a country's growth. Countries that have expanded their women's intensive manufacturing and service sectors experienced economic growth well. This shows the role of women in a country is important to be seen (Humphries \& Sarasúa, 2012; Ross, 2018). Highlights of the latest evidence the women have various contributions and participation in the field of economics (Kazandjian et al., 2019), and also improvement from the decline in the business cycle (Peiró et al., 2012; Fukui et al., 2019).

Empowering female heads of the household does not always provide members with financial support. The assistance is more towards developing skills in the form of savings and loans, education, to legal protection (Kuswanti et al., 2020). For those who work as farmers or traders are given the education to develop their business. While those who do not have skills are given provision in skills, development such as sewing, beauty, baking, and developing according to their talents, those who do not have capital can through savings and loan cooperatives that they can increase family income. Pekka members also get help to connect with other companies or organizations to help with their work. Then, providing legal protection, such as obtaining a family card, making identity cards, making birth certificates, divorce management assistance, and assisting reporting cases to the police.

Pekka group members still need the court both legally and in the community as the main family breadwinner (Yusrina et al., 2011). The fact that Pekka has a very significant role both as the head of the family and as a breadwinner for the family, while the implication that Pekka in its activities meets family livelihoods is still experiencing limitations. Therefore, it requires special attention from the government, social institutions, and the wider community and the need to strengthen Pekka's position by the state normatively and in terms of policies that can improve the living standards of Pekka group members (Asni, 2018).

Previous research in traditional societies such as Pakistan, all major, and small Men have authority both inside and outside the house (Mujahid et al., 2015). In reality, in India empowerment and achievement of objectives is strongly influenced by gender equality as well as in education access and employment (Nayak \& Bidisha, 2010). Therefore, strong commitments are needed, especially the government, families, schools and communities (Aboo \& Khalid, 2014), Women as grassroots active in development 
so as to realize women's empowerment. Women as a measure of family independence that prioritizes the interests of children, husband, extended family, and the surrounding community as a binding identity. (Soetjipto et al., 2015) the importance of overcoming domestic violence (domestic violence). The role of women is also dominant, although they often face obstacles in implementing it (Kuswanti et al., 2020).

The Empowerment of female household heads in Batang, Central Java, was the focus of this study. Through praise in Pekka, Batang is an extension of Central Pekka (Pekka centers are in Bekasi), Pekka Batang escorts are very interesting for researchers because the Batang Pekka group is very simple both conditions and its location in the countryside, but enthusiastic members (housewives) with diverse backgrounds and based on praise they are very minimal with knowledge. The role of women in the public sector, in the Pekka Batang group, includes small traders, food stalls, housemaids, salons, tailors, farm laborers, factory workers, shopkeepers and trading in the market.

At present, the Pekka program in Batang-Central Java Regency is an important subject in women's development. In the process certainly, members of Pekka groups do not immediately become empowered and independent, as (Novek, 1999) said to realize social change, people will communicate to build a society and act together to make it happen, as well as what happens in Pekka groups, they have been fostered and assisted through communication withi.n the group which is realized by the training and skill development of each Pekka member. Many things have been communicated within the Pekka group, ranging from general issues to problems of the situation and suggestions for future self-improvement. Pekka groups are considered a good place to empower Pekka members.

According to (Curtis et al., 2005) states group communication is established when three or more people face to face, usually under the direction of a leader to achieve common goals or goals and influence one another. Effective group communication can be created by first getting to know the members well with each other. Group communication is important in carrying out information disclosure between members and the chairperson, so there are no communication obstacles, and behaving honestly so as not to cause new problems (Primantara, 2016). According to (Indardi, 2016), successful development, priority in empowering the community in the economic sphere, is needed by the important role of communication

Based on previous research that has been reviewed, it produces newness in different studies, especially when viewed from a bona fide group communication approach that is associated with Pekka's economic empowerment. Pekka group communication activities in which cybernetic tradition is closely associated with group participation (Littlejhon \& Foss, 2012) say's view of Input-process-Output in building groups is through (1) environmental impact due to the inclusion of information (Input), (2) group processing of information (process), and (3) both inside and outside individual groups are strongly influenced by the results (outputs).

Through communication within the Pekka group, it is hoped that they will be able to interact more easily so that the obstacles they perceive as threats to become empowered have been reduced or can even be removed. Empowerment will contribute greatly to people's lives. Contributions include a variety of knowledge and skills as well as good methods to be able to maximize all the potential that exists in individuals and the potential that exists in their environment. Based on the explanation above, this study aims to: (1) identify the characteristics of Pekka groups and Economic Empowerment, 
(2) analyze the effect of the characteristics of Pekka groups on Economic Empowerment, and (3) analyze the effects of communication within the Pekka group.

\section{Methods}

This study uses a post-positivism paradigm, through a mixed-method approach, which is quantitative and strengthened by qualitative analysis Focussed Group Discussion (FGD), with a survey method in Batang, Central Java. The population in this study was female head of household in Batang District, the Pekka group in Batang district was one of the many active Pekka groups. It was continuing to increase development for the empowerment of group members. Besides, the high number of female heads of household in Batang District makes the writer interested in researching at this location. The total population of Pekka members in Batang Regency was 535. Then twelve villages were selected.

Research sampling method with stratified random sampling or Layered random sampling. This is due to the condition of the population that is of interest in sampling in this study is divided into several strata, namely 12 (twelve) villages. According to (Scheaffer et al., 2012) stratified random samples are samples obtained by dividing populations into groups that do not overlap, and then taking randomly from each group. The group is called a layer or stratum. The characteristics of the members in each village are assumed not to be homogeneous, therefore the basis for the strata in the sampling of this study is the village. The number of samples obtained using the Slovin formula were 229 Pekka members. The research lasts ten months, starting from March to December 2019. Primary data was collected from Pekka members. Description analysis is used to see the average score on Pekka groups' characteristics and economic empowerment using SPSS 22.0. Inferential analysis shows the effect of Pekka characteristics of economic empowerment groups using Structural Equation Modeling (SEM) LISREL 8.8 .

\section{Results}

The Average Score of The Characteristics of the Group of Female Heads of Household (Pekka)

In Table 1, it can be seen that the average score of each indicator varies with the highest accompanying role indicator and the lowest information access. The indicator sequence in more detail is the role of the companion having the highest average score of 3.09 followed by the role of the group 2.93, the role of cadres with a score of 2.42 , the role of administrators 2.40 and the lowest score on information access with a score of 1.96. The average total score on the Pekka group's characteristics was considered good, with a total of 2.56 .

Pekka members, in good categories, assessed the role of companion and group role. This is in line with the findings in the field; the facilitator has a role and function as well as a high level of trust for Pekka group members. Meanwhile, the role of the cadres, the role of the management, and the role of the group is considered bad. Cadres and administrators still do not understand their roles and functions well; this certainly can be input material so that in the future, they will further develop the roles and functions of cadres within Pekka groups. Furthermore, the Pekka group's access to information was considered a very bad category. This condition is an interesting new finding in the study, considering that access to information is important in harmonizing 
ideas and ideas and avoiding the delay of Pekka group members in obtaining information. The results are presented in Table 1.

Table 1. Distribution of the Average Score of the Variable Characteristics of Pekka (2019)

\begin{tabular}{cc}
\hline Variable Characteristics of Pekka Groups & Average Score* \\
\hline Information Access & 1.96 \\
Role of the Group & 2.93 \\
The Role of Management & 2.40 \\
The Role of Cadres & 2.42 \\
The Role of Companion & 3.09 \\
Total & 2.56
\end{tabular}

Note: *Very Bad: 1-1.75, Bad: 1.76-2.51, Good: 2.52-3.27, Very Good: 3.28-4

The Average of Score Economic Empowerment for Women Heads of Households

According to (Ginandjar, 1996) empowerment of the people's economy is 'an effort which is the mobilization of resources to develop the economic potential of the people and increase people's productivity so that both human resources and natural resources around the people's existence, productivity can be increased.' From various views on the concept of empowerment, it can be concluded, that economic empowerment of the community strengthens ownership of the factors of production, strengthens the mastery of distribution and marketing, strengthens the community to get adequate salary/wages, and enhances the community to obtain information, knowledge, and skills, which must be done in various aspects, both from the aspect of society itself, as well as from the aspect of policy.

Table 2 shows the average score of each indicator of economic empowerment varies, indicators of capital access get the highest score and the lowest management skills. The indicator sequence in more detail is that access to capital has the highest average score of 2.67. Furthermore, followed by risk management indicators 2.57, business assistance indicators with an average score of 2.52, and the lowest score on skill management with an average score of 2.39. The average total score on the Pekka group's economic empowerment variables has been assessed as good, with an average total score of 2.53. The results are presented in Table 2.

Table 2. Average distribution of Economic Empowerment scores (2019)

\begin{tabular}{cc}
\hline Variable of Economic Empowerment & Average score* \\
\hline Capital Access & 2.67 \\
Business Assistance & 2.52 \\
Skill Management & 2.39 \\
Risk management & 2.57 \\
Total & 2.53 \\
\hline
\end{tabular}

Note: *Very Bad: 1-1.75, Bad: 1.76-2.51, Good: 2.52-3.27, Very Good: 3.28-4 Effect of Characteristics of Pekka Groups on Economic Empowerment

The results of processing for the goodness of fit test show that by using the Chisquare test, the conclusion is p-value $0.000<0.05$ so that $\mathrm{Ho}$ is rejected and $\mathrm{Ha}$ is accepted, which means the resulting model shows that the model is not good, but we can see the other goodness of fit because data and models influence the chi-square. Besides, SEM provides an alternative use of other goodness of fit indicators. RMSEA criteria produce a value of $0.078<0.08$, which means that the resulting model is the goodness of fit.

The use of other goodness of fit criteria, namely GFI, NFI, and CFI, produces a value $>0.9$, which means the resulting model has the goodness of fit. Because the results 
of the conclusions of several indicators produce the conclusion of the model of the goodness of fit, the theoretical hypothesis testing can be done. The results are presented in Table 3.

Table 3. Testing the 2019 Goodness of fit model

\begin{tabular}{cccc}
\hline Goodness-of-Fit & Cutt-off-Value & Result & Conclusion \\
\hline $\mathrm{X}^{2}$ - Chi-square & Expected to be small & 45.59 & Fit \\
Significance & $\geq 0.05$ & $\mathrm{P}=0.00057$ & \\
RMSEA & $\leq 0.08$ & 0.078 & Fit \\
GFI & Approaching 1 & 0.98 & Fit \\
NFI & Approaching 1 & 1.00 & Fit \\
CFI & Approaching 1 & 1.00 & Fit \\
\hline
\end{tabular}

Note: RMSEA (Root Mean Square Error of Approximation), CFI (Comparative Fit Index), GFI (Goodness of Fit Index), IFI (Incremental Fit Index), NFI (Normed Fit Index)

Through this research, the characteristics of Pekka groups influence positively directly on economic empowerment. This section is focused on seeing how the characteristics of Pekka groups affect economic empowerment. The effect between variables can be seen from Figure.

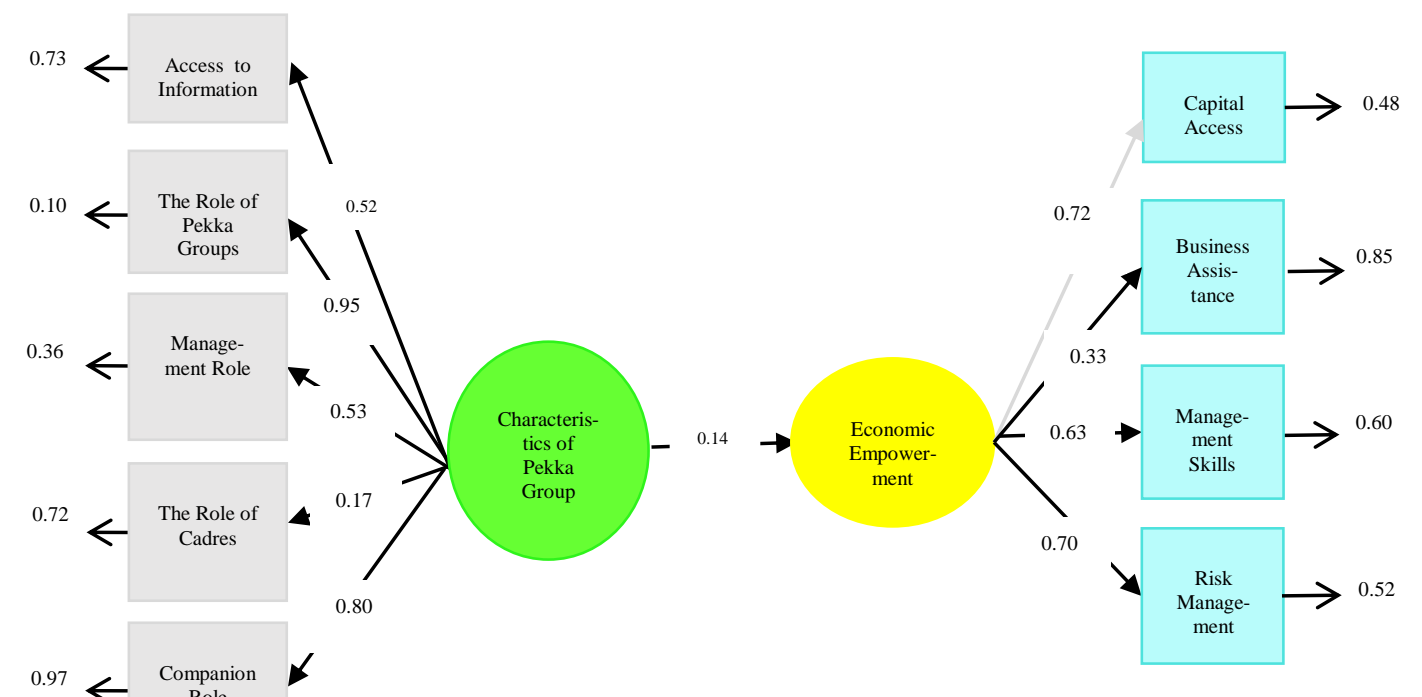

Chi-Square: 38.77 , df: 22, p-value: 0.01499, RMSEA: 0.058

Figure 1. Pekka Economic Empowerment Model (2019)

(source: SEM Analysis of the Authors, 2019)

Based on the picture above shows the results there are five supporting indicators of the characteristics of Pekka groups with the most dominant percentage value on the group role indicator 0.95 , followed by the companion role indicator 0.80 , the management role indicator 0.53 , an indicator of information access 0.52 and indicators finally the role of cadres with the lowest percentage is 0.17 . In line with the results of the average score of group roles and the role of the companion still dominates the highest results of the indicators by contributing most in encouraging variable characteristics of Pekka groups. The role of the companion and the role of the group is directly related to the behavior and behavior of the companion as a person who has a 
contribution in developing the skills of Pekka members so that a Pekka group is developed and continues to develop.

The amount of determination with the highest value on the dependent variable of economic empowerment is four indicators, with the percentage of each in the capital access indicator 0.72 , followed by a risk management indicator 0.70 , skill management indicators 0.63 , and the last indicator on business assistance 0.33 . This is in line with the results of the average score, which results in the model's access to the indicator that has the highest contribution in encouraging economic empowerment variables. Access to capital is certainly important so that Pekka members can become independent and empowered to continue to grow and support their family's economy. Access to capital that has been carried out in the Pekka program is related to access to venture capital and loan capital.

Access to capital will also increase the confidence of women household heads because they try to think of all risks by applying the knowledge and skills they have received while joining women household groups. Characteristics of women-headed household groups ( $\zeta 1)$ have a direct positive effect on economic empowerment $(\eta 1)$. From the processing, results obtained it is estimated that the coefficient is 0.14 , which means that the higher the characteristics of Pekka groups $(\zeta 1)$, the higher the economic empowerment $(\eta 1)$ directly and vice versa. Characteristics of Pekka groups with indicators that will be able to increase Pekka's economic empowerment. This result shows that the proposed theoretical hypothesis is proven with a statistical value of 4.65> t-table 1.96, which means that Ho is rejected, so it can be concluded that there is a

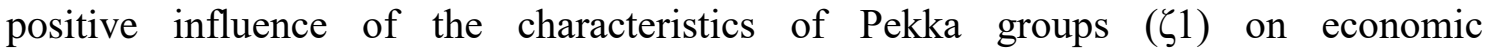
empowerment $(\eta 1)$. The results are presented in Table 4.

Table 4. Testing hypotheses theory

\begin{tabular}{ccccc}
\hline Path & Estimate & S.E. & $\begin{array}{c}|\mathrm{t}-\mathrm{hit}|> \\
1.96\end{array}$ & Conclusion \\
\hline & Live & & & \\
$\begin{array}{c}\text { Group Characteristics -> } \\
\text { Economic Empowerment }\end{array}$ & 0.14 & 0.031 & 4.65 & Significant \\
\hline
\end{tabular}

Note: significant at $\mathrm{p}<0.05$, with $\mathrm{t}$-value $>\mathrm{t}$-table (1.96)

Communication Effects in Pekka Group

Based on the Focussed Group Discussion (FGD) that has been carried out, it explains the findings that the presence of Pekka as a group facilitated through mentors can improve other skills beyond the offered program, namely communication skills as conveyed by members in the FGD (2019): "The companion helps us to be more confident, starting from attitude, mentality and also communication in daily life, every meeting requires us to be active and always provide us with new knowledge, so we don't miss information. The companion also continued to encourage us. In fact, many of my friends in the Pekka group are not ashamed to be presenters at village events, there are also friends who often take an active part in seminars and always express their opinions in every meeting."

This is in line with research findings, that the communication activities that are often carried out create Pekka group members to be critical, information-hungry, empowered, independent, and potential, and also have better public speaking skills than before they joined the Pekka group. 


\section{Discussion}

Differences in gender perceptions between men and women are closely related to the dynamics of the roles and responsibilities of men and women in the household and society. Vulnerable that women are more responsible for managing the internal affairs of the family so that they are more vulnerable to the factors of powerlessness. Therefore this gender equality movement does not question differences between men and women in terms of only anatomical biology or gender and examines social, cultural, psychological, and other non-biological aspects (Nuraida \& Zaki, 2018).

As stated earlier, gender equality can also show the similarity of gender equality is a development fruit that provides equal rights opportunities between men and women as human beings, to portray its participatory function in both economic, political, sociocultural, legal, educational, defense and national security activities. is characterized by the absence of discrimination between women and men in all accesses. Men and women have access mean having the authority to make decisions and have the same opportunity to use resources (Muzakkir, 2018).

Women are often considered to be the second person who only helps the partner (subordinate), is poorly educated, and has limited skills to produce economic contributions to the family (Nugroho, 2008) among these factors are unemployed husbands who cannot provide a living, prices high consumption goods, the cost of education and health costs continues to increase, and debt problems that continue to wrap around his life. This is certainly a motivation for women household heads to become empowered and independent. Assistance is needed to motivate Pekka members to become empowered and independent.

Research (Almås et al., 2018) which was strengthened by (Kushandajani, 2019) explained if women were prioritized in development empowerment programs including health, education, minimization of domestic violence, agriculture, entrepreneurship, and poverty alleviation. The implication, women make many positive contributions to women's empowerment.

Based on the results of the average score on the characteristics of Pekka group characteristics, the results of the indicators of the role of the companion and the role of the group were assessed well by Pekka group members. The group will feel comfortable with Group Support, routinely attending group meeting (Setiawan L, 2014). The role of groups, as in the research of (Mauludin et al., 2012), is said to be one of the strategies that can be utilized in improving the quality of empowerment for farmers so that empowerment is an increase in the role of farmer groups. In other research, it is said that the group approach is seen as more efficient and can be a medium for the learning process and interaction of the farmers. It is expected that there will be changes in farmers' behavior towards better or quality (Margono, 2001).

The role of the group is not only that, the group's role is to form a sense of unity between members in line with this (Setiawan, 2009) said the existence of group activities in the form of member creativity would lead to friendly relations and this is applied to Pekka groups. The role of the group is a place to be able to develop and improve the abilities and new knowledge of group members, by conducting training related to empowerment such as empowerment in the field of catering (making processed chips, making processed snacks), governance make-up, fashion and training related to the vision and mission to increase the confidence of Pekka group members.

The role of the group is also a forum for sharing complaints and information among Pekka members. Communication activities will certainly be the key to creating 
good relations among Pekka members. As said (Saputra, 2012) in communicating activities, the effects of changes are expected to occur not only to someone but also to the people of the community. Recipient audiences consisting of many people, are targeted by communication messages that are expected to be effective.

The average results on the variables of economic empowerment, indicators of capital access, business assistance, and risk management were assessed well by Pekka members. Indicators of capital access are considered good with a high percentage by Pekka groups.Sources of venture capital can be obtained from its capital, government assistance, financial institutions, both banks, and non-bank financial institutions. Capital is a business factor that must be available before carrying out activities. The capital size will affect business development in the achievement of income (Riyanto, 2001), another meaning of capital, including both capitals in the form of money and the form of goods. Pekka's economic empowerment must continue to be supported and not only focus on four indicators, bearing in mind that there are still many other indicators that are able to encourage economic empowerment, especially those related to group communication (limitations/weaknesses).

Economic empowerment within the Pekka group is still ongoing. The companion is aware of the first obstacle in empowering group members to be able to realize economic independence based on access to capital, in this case, the companion tells the author that there are several forms of empowerment that have been carried out so far. "... usually, in the beginning, we made Rp. 500.000 for small businesses first. Until now continued. We continue to strive to continue to do capital development and assistance. We see that it is indeed serious for entrepreneurship so that we continue to be encouraged to become more independent because this Pekka is an independent organization, so we do not expect much help from the government, so we select people who can receive access to venture capital" (Counterpart, 2019).

In line with this, Pekka members also said that in another interview, it was said that for several years, entrepreneurial activities were funded by Pekka and continue to this day. "I have been in Pekka for six years, at first, I was diligent in training, and then I was offered to be given venture capital until now I am still advanced. I also plan to early this month (November 2019) to want a rice trading business. I am also used to the activities that I live; I can share time for family and entrepreneurship to keep going. I want other members to be like me" (Pekka Member, 2019).

Consistent access to capital that has been carried out within Pekka members so far is certainly a relief because basically Pekka members who already have the expertise or independent abilities but sometimes they do not have the provision to open a business, through this Pekka group they can get capital loans to open a small business. In addition, risk management indicators are the second indicators assessed by Pekka members with a high percentage, meaning that Pekka groups can avoid business risks, minimize business risks and have good risk analysis skills, coupled with business assistance that has been carried out by a companion so far.

This assistance is intended as a forum for overcoming various Pekka group problems and also conducting various training by involving people who are experts in their fields to help empower Pekka group members. Community empowerment efforts carried out so far, with various forms and variations, are carried out to improve community welfare and community independence. One of the efforts to empower is carried out with assistance. (Jamaris, 2016) explained that assistance is an effort to invite and guide the community (individuals or groups) to develop various potentials to 
achieve a good quality of life. As explained earlier, assistance in training accelerates skill improvement; Also, assistance has a major influence on efforts to increase women's economic empowerment. Seeing that good conditions have been created in the aspect of economic empowerment indicators, which are influenced by indicators in group characteristics, in the future, it is only necessary to maintain and develop periodically so that Pekka's economic empowerment continues to run well.

SEM processing results show, it can be concluded that Pekka groups' characteristics have a significant positive effect on economic empowerment. Economic empowerment achieved through the role of Pekka groups includes assisting businesses to bring in additional income, the ability of risk management so that they are more empowered in overcoming various problems and find solutions quickly and readily, as well as the courage to take risks both in the small decisions of their lives or large decisions. This is certainly an interesting finding, considering that Pekka group members were initially only housewives who did not have the ability and courage to take risks that were considered contrary to nature as women. But now, most Pekka group members have been able to empower and become independent. The achievements that have been achieved by Pekka group members certainly cannot be separated from group communication carried out within Pekka groups.

Group communication plays an important role in a relationship, such as relationships within institutions, companies, organizations, or communities. Simple communication activities do not just convey information messages but also contain persuasive elements so that other people are willing to accept an understanding and influence and carry out an order, seduction, and so on. Within the community or Group, it is very important to process effective group communication because it can cause good feedback in the community. Groups need communication to support cohesiveness in a group. Group communication is important in human life because groups are an integral part of our daily activities. Besides that, the group allows us to share information, experiences, our knowledge with other members (Ririn, 2016).

In a community, there is a group communication process. According to (Wiryanto, 2005), group communication is interpersonal between one member with another in order to share information, solve and find solutions to problems together, and each member remembers the other members well. The process of group communication that occurs within the group influences what they expect, as in the Pekka group, the group formed aims to promote, improve, and empower women household heads in Batang District.

Special conditions where group communication is known as bona fide group theory or group theory is trusted. This theory is in the cybernetic tradition and put forward by Stohl and Putnam. Bonafide means trustworthy (bona fide), whereas a bona fide group is a naturally formed group. This theory explains that groups have two characteristics. Namely, they have boundaries that can be penetrated and are interdependent with the environment. Sometimes in-group or out-group almost don't see the difference. According to this theory, humans are not closed with the existence of other groups and result in humans not having the same commitment in a group (Littlejhon \& Foss, 2012). This theory also explains that interaction between one Group and another results in cooperation or conflict.

In connection with the theory of bona fide group communication in (Ginting, 2009) concerning the relationship between group communication skills and increased community participation in the Inpres Village underdeveloped ('Inpres Desa 
Tertinggal' (IDT)) program, it can be seen from the results of research that there is effectiveness in the implementation of the IDT program after collaboration and adjustment of the information provided in groups. The better the collaboration, the better the community participation in the IDT program. Also, (Budhirianto, 2015) research on group communication patterns for the empowerment of Community Information Groups (KIM) in the success of food self-sufficiency. It is known that the results of the research show that communication patterns constructed through stakeholders to the farming community are carried out with more directed and integrated group communication. Empowering existing farmer group communities (KIM) needs to be maintained with an optimal communication paradigm. That is, group communication is considered the best solution in directing the community to the success of food self-sufficiency.

In line with this (Zulminarni \& Fox, 2019) said the training approach of women's household heads is participatory, driven by curiosity, joy, and friendship, and makes women's policies and practical knowledge a source of inspiration. Members analyze real problems, develop strategies to implement, and learn how to deal with the unavoidable challenges and conflicts that arise. When women take action, Pekka activists provide opportunities for them to reflect critically on their experiences so they can learn from their successes and failures. Emphasis on empowerment includes awareness-raising, power analysis, and negotiation skills.

The results showed that the communication of bona fide groups established within the Pekka group resulted in collaboration. This is based on solidarity between members in Pekka groups. The role of groups, as explained above, shows a major contribution to increasing empowerment. Good cooperation, mutually motivating, and developing themselves together in Pekka groups are characteristic of Pekka Batang groups in realizing economic independence. The findings show that conflicts within the Pekka group are rare. All matters relating to the program to empower Pekka's economic independence will result in collaboration within Pekka members to realize economic empowerment. In Pekka groups, all aspects continually work hand in hand to improve economic independence through training offered in the group, such as assistants acting by their roles and functions to direct Pekka members and train Pekka members to become skilled by the programs made. Pekka members also did not let go of their hands and only received assistance. (Ganesh \& Zoller, 2012) Cooperation by establishing good communication and interconnected can be done by dialogue. Pekka members also help one another to get together the same knowledge, expertise, or skills.

(Stavrositu \& Sundar, 2012) argue, in the end a strong sense of empowerment will show the affordability of women. Strengthened by (Antunovic \& Hardin, 2013; Sinanan et al., 2014), in demonstrating personal beliefs and values, women tend to have a strong and independent sense. Experiential has the relationship needed with empowerment, meaning that the important role of empowered women is important (Levina, 2014). Which will involve women to be something unique by being empowered (Mann, 2014; Marwick, 2015). Opinions (Friedman, 1994) about the empowerment approach put pressure on community group decision-making based on individual resources, direct (through active participation), and direct social learning. By empowering the community in the economy and politics, it is expected that the community will have a good and advanced bargaining position. Pekka's economic empowerment was also said in an in-depth interview that many Pekka members have dared to take risks to become entrepreneurs. They already have the confidence and 
ability as well as knowledge on how to skilled management and risk management by minimizing business risks for entrepreneurship. Most Pekka members have successfully applied the principle of community empowerment. Empowering women can be done through the development of skills both in quantity and quality as potential human resources (Mardikanto, 2014). Women's household heads empowerment program to increase income through handicraft training; business development; skills training; education. The Pekka program's role to Pekka participants through the existence of an independent business capital loan to increase handicraft productivity can add to the side work of doing business in groups. The Pekka program can increase the income of Pekka participants (Kuswanti et al., 2020). There are also major constraints faced by Pekka, including reproductive roles, and communication (Yustitin et al., 2016). Pekka members are very motivated to progress both conceptually and materially. Most Pekka members have been able to be independent, make appropriate decisions, analyze problems, discuss issues to find solutions to problems, and support their family's economy.

\section{Conclusion}

The results in field, it can be concluded that the average score of the Pekka group's characteristics is in a good category, with the highest indicator on the role of the companion. In the economic empowerment variable shows good results with the highest indicator of access to capital. Based on SEM analysis, it can be concluded that the characteristics of Pekka groups influence economic empowerment.Pekka groups have proven to be able to become a forum for empowering Pekka group members. Effective communication of Pekka groups has been able to create competitive groups. Effective group communication is created through Pekka groups, both between members and groups, groups and groups, or members with facilitators; this causes the group to develop well, coupled with the creation of good closeness within Pekka groups, they know members of one group. With the others first well so that it has a close emotional closeness. The Pekka group aims to establish and empower women household heads in Batang District. Pekka groups in Batang Regency have headed for good economic empowerment. However, there are still some obstacles that can slow down the speed of economic empowerment in the process. Therefore, as seen from the variable characteristics of Pekka groups in the indicators of the roles of the management and cadres that are considered to be still not optimal, it certainly becomes an input for Pekka groups to be able to develop the roles and functions of management and cadres to maximize the future economic empowerment. The author also provides suggestions for future research in order to be able to trust the analysis of communication in economic empowerment which is not only fixed on four indicators, but can be directly linked to communication within a group.

\section{Conflict of Interest}

I declare that this research is indeed my writing and there are no conflicts of interest whatsoever in the process of preparing this research.

\section{Acknowledgments}

Acknowledgments the authors convey to the Central Pekka, who has recommended the author to conduct research in Batang, Central Java. Next, to the Pekka group in Batang District, who have become respondents in this study. For their 
cooperation and assistance in answering questionnaire questions in order to complete the results of the study to complete this research, the authors say thank you.

\section{References}

Aboo, K., \& Khalid, T. (2014). Women and politics: Social construction and deconstruction. Research Gate Journal, 10(3), 104-113. https://doi.org/10.3844/jsssp.2014.104.113

Almås, I., Armand, A., Attanasio, O., \& Carneiro, P. (2018). Measuring and Changing Control: Women's Empowerment and Targeted Transfers. Economic Journal, 128(612), F609-F639. https://doi.org/10.1111/ecoj.12517

Antunovic, D., \& Hardin, M. (2013). Women bloggers: identity and the conceptualization of sports. SAGE Journal, 15(8), 1374-1392. https://doi.org/https://doi.org/10.1177/1461444812472323

Asni. (2018). Perempuan kepala keluarga dan pencari nafkah di pasar Baruga Kabupaten Kendari dalam perspektif hukum Islam. Jurnal Hasil-Hasil Penelitian, 12(1), 67-84. https://doi.org/http://dx.doi.org/10.31332/ai.v12i2.641.

Baer H. (2016). Redoing feminism: digital activism, body politics, and neoliberalism. Research Gate Journal, 16(1), 17-34. https://doi.org/https://doi.org/10.1080/14680777.2015.1093070

[Bappenas] Badan perencanaan dan pembangunan nasional. (2013). Pembangunan Kesetaraan Gender Background Study RPJMN III (2015-2019). Bappenas Pers.

Budhirianto, S. (2015). Pola Komunikasi untuk Pemberdayaan Kelompok Informasi Masyarakat dalam Menyukseskan Program Swasembada Pangan. Jurnal Pekommas, 18(2), 127-138. https://doi.org/10.30818/jpkm.2015.1180206

Curtis, Floyd, James, Winsor, \& Jerry. (2005). Komunikasi Bisnis dan Profesional (8th ed.). PT Remaja Rosdakarya.

Friedman, J. (1994). Empowerment The Politics of Alternative Development (1st ed.). Blackwell Publishers.

Fukui, Nakamura, \& Steinsson, J. (2019). Women, Wealth Effects, and Slow Recoveries. National Bureau of Economic Research Working Paper, 23(3), 2531.

Ganesh, S., \& Zoller, H. (2012). Dialogue, activism, and democratic social change. The Commun Journal, 21(1), 66-91. https://doi.org/https://doi.org/10.1111/j.14682885.2011.01396.x

Ginandjar. (1996). Pembangunan untuk rakyat: memadukan pertumbuhan dan pemerataan. (1st ed.). PT Pustaka Cidesindo.

Ginting. (2009). Hubungan antara kemampuan komunikasi kelompokdengan peningkatan partisipasi masyarakat dan efektivitas pelaksanaan program IDT. Pekommas, 18(2), 128-137.

Hasinoff. (2014). Contradictions of participation: critical feminist interventions in new media studies. Communication and Critical/Cultural Studies Journal, 11(3), 270272. https://doi.org/https://doi.org/10.1080/14791420.2014.9 26242

Hubeis, A. (2010). Pemberdayaan Perempuan dari Masa ke Masa (1st ed.). IPB Press.

Humphries, J., \& Sarasúa, C. (2012). Off the Record: Reconstructing Women's Labor Force Participation in the European Past. Feminist Economics Journal, 18(4), 3967. https://doi.org/https://doi.org/10.1080/13545701.2012.746465

Indardi. (2016). Pengembangan Model Komunikasi dalam Pemberdayaan Masyarakat Tani (Studi Kasus pada Kelompok Tani Jamur Merang Lestari Makmur di Desa 
Argorejo, Sedayu, Bantul). Journal of Agribusiness and Rural Development Research, 2(1), 75-86. https://doi.org/10.18196/agr.2128

Jamaris. (2016). Kompetensi Pendamping Pembangunan Desa. 1-36. https://www.researchgate.net/publication/324221842_KOMPETENSI_PENDAM PING_PEMBANGUNAN_DESA_PROSIDING_SEMINAR_NASIONAL

Kabeer, N. (2010). Women's empowerment, development interventions and the management of information flows. IDS Bull Journal, 41(6), 105-113. https://doi.org/. https://doi.org/10.1111/j.1759-5436.2010.00188.x

Kazandjian, Romina, Kolovich, L., Kochhar, K., \& Monique. (2019). Gender Equality and Economic Diversification. Social Science Journal, 8(4), 42-118.

Kushandajani. (2019). Social and Economic Empowerment for Village Women as a Strategy of Village Development. The Indonesian Journal of Planning and Development, 4(1), 1. https://doi.org/10.14710/ijpd.4.1.1-6

Kuswanti, A., Saleh, A., Vitalaya S Hubeis, A., Puspita Sari, H., \& Abdul Muqsith, M. (2020a). Effect Of Group Participative Communication and Economic Empowerment Of Independent Women. The Journal Of Social Sciences Research, 6(3), 293-299. https://doi.org/http://doi.org/10.32861./jssr.63.293.299

Kuswanti, A., Saleh, A., Vitalaya S Hubeis, A., Puspita Sari, H., \& Abdul Muqsith, M. (2020b). The Impact Of Regulation Policy In Indonesia Against: Women Family Head. Jurnal Cita Hukum, 8(1), 103-122. https://doi.org/10.15408/jch.v8i1.14264

Kuswanti, A., Saleh, A., Vitalaya S Hubeis, A., Puspita Sari, H., Muzykant, V. L., \& Abdul Muqsith, M. (2020). Effect Of Group Participative Communication Toward Pekka Economic Empowerment. Internsational Journal Of Advances Science and Technology, 29(3), 238-249.

Levina. (2014). From feminism without bodies, to bleeding bodies in virtual spaces. Communication and Critical/Cultural Studies Journal, 11(3), 278-281. https://doi.org/https://doi.org/10.1080/14791420.2014.926243

Littlejhon, S., \& Foss, K. (2012). Teori Komunikasi. Salemba humanika.

Mann, L. (2014). What can feminism learn from new media? Communication and Critical/Cultural Studies Journal, 11(3), 293-297. https://doi.org/https://doi.org/10.1080/14791420.2014.926244

Mardikanto, T. (2014). Corporate Sosial Responsibility (Tanggungjawab Sosial Korporasi) (2nd ed.). Alfabeta.

Margono, S. (2001). Paradigma Baru Penyuluhan Pertanian Di Era Otonomi Daerah. 1-56. file:///C:/Users/user/Downloads/5120-8601-1-SM.pdf

Marwick, A. (2015). Instafame: luxury selfies in the attention economy. Publ Cult Journal, 27(1), 137-160. https://doi.org/https://doi.org/10.1215/089923632798379

Mauludin, M. A., Winaryanto, S., \& Alim, S. (2012). Peran kelompok dalam mengembangkan keberdayaan peternak sapi potong (kasus di wilayah Selatan Kabupaten Tasikmalaya ). Jurnal Ilmu Ternak, 12(1), 1-8.

Mujahid, N., Ali, M., Noman, M., \& Begum, A. (2015). Dimensions of women empowerment : A case study of Pakistan dimensions of women empowerment: A case study of Pakistan. Journal of Economics and Sustainable Development, 6(1), $37-45$.

Muzakkir, M. (2018). Membincangkan relasi gender dalam perspektif komunikasi (Studi Kasus Terhadap Public Speaking Versus Private Speaking di Aceh Barat). SOURCE: Jurnal Ilmu Komunikasi, 4(1), 13-25. 
https://doi.org/10.35308/source.v4i1.917

Nayak, P., \& Bidisha, M. (2010). Women empowerment in India. SSRN Electronic Journal, 3(1), 1-32. https://doi.org/doi:10.1007/978-981-10-4268-3_1.

Novek, E. (1999). Communication and community empowerment. Peace Review, 11(1), 61-68. https://doi.org/https://doi.org/10.1080/10402659908426231

Nugroho, R. (2008). Gender dan Strategi Pengarus-Utamanya di Indonesia (1st ed.). Pustaka Pelajar.

Nuraida, N., \& Zaki, M. (2018). Pola Komunikasi Gender Dalam Keluarga. Jurnal Wardah, 18(2), 181. https://doi.org/10.19109/wardah.v18i2.1780

Peiró, Amado, Jorge, B.-F., \& Teresa, G. M. (2012). Unemployment, Cycle and Gender. Journal of Macroeconomics, 34(4), 75-167.

[PIPEL \& LAN] Pusat inovasi pelayanan publik dan lembaga administrasi negara. (2018). Model inovasi berbasis gender menumbuhkembangkan wirausaha perempuan (Marsono \& T. Gayatri (eds.)).

Portwood, S. (2014). Feminism and participation: a complicated relationship. Communication and Critical/Cultural Studies Journal, 11(3), 298-300. https://doi.org/https://doi.org/10.1080/14791420.2014.926246

Primantara, V. C. (2016). Komunikasi Kelompok Pada Kelompok Srikandi Khayangan dalam Mewujudkan Kemandirian Sebagai Mitra Binaan PT. Pertamina EP. Pangkalan Susu. Jurnal Simbioka, https://doi.org/https://doi.org/10.31289/simbollika.v2i1.220

Ririn, T. (2016). Komunikasi Dalam Komunikasi Kelompok. Jurnal Komunikasi UAD, 4(1), 81-90. https://doi.org/10.12928/channel.v4i1.4208

Riyanto, B. (2001). Dasar-dasar Pembelanjaan Perusahaan (4th ed.). BPFE.

Ross, M. (2018). Oil, Islam, and Women. American Political Science Review Journal, 102(1), 23-107.

Saputra, A. (2012). Memahami pola komunikasi kelompok antar anggota komunitas punk di Kota Semarang. Jurnal The Messenger, IV(1), 43-62. https://doi.org/http://dx.doi.org/10.26623/themessenger.v4i1

Scheaffer, R., Mendenhall, W., \& Ott, R. (2012). Elementary Survey Sampling. Duxbury Press.

[Seknas] Sekretaris nasional Pekka. (2014). Profile Pemberdayaan Perempuan Kepala Keluarga. http: \%5C\%5Cseknas@PEKKA.or.id.

Setiawan L. (2014). Memahami Proses Komunikasi Kelompok Pecinta Ayam Jago Aduan di Kawasan Manyaran. Jurnal The Messenger, VI(2), 17-28. https://doi.org/http://dx.doi.org/10.26623/themessenger.v6i2

Setiawan, Y. B. (2009). Memahami komunikasi kelompok dalam pendampingan korban kekerasan berbasis gender. Jurnal The Messenger, 1(1), 48-59. https://doi.org/10.1017/CBO9781107415324.004

Sinanan, J., Graham, C., \& Zhong, J. K. (2014). Crafted assemblage: young women's 'lifestyle' blogs, consumerism and citizenship in Singapore. Vis Stud Journal, 29(2), 201-213.

Soetjipto, A., Soetjipto, W., \& Adelina, S. (2015). Pemberdayaan Perempuan Desa. Jurnal Aspirasi, 6(1), 203-212.

Stavrositu, C., \& Sundar, Ss. (2012). Does blogging empower women? Exploring the role of agency and community. Journal of Computer-Mediated Communication, 17(4), 369-386. https://doi.org/https://doi.org/ 10.1111/j.1083-6101.2012.01587.x

Wiryanto. (2005). Pengantar Ilmu Komunikasi (4th ed.). Grasindo. 
Yusrina, A., Budiyati, S., \& Yumna, A. (2011). Akses terhadap keadilan: pemberdayaan perempuan kepala keluarga di Indonesia (Studi Kasus di Provinsi Nanggroe Aceh Darussalam, Jawa Barat, Kalimantan Barat, dan Nusa Tenggara Timur). Lembaga penelitian Smeru.

Yustitin, N., Sukardi, \& Supartiningsih, S. (2016). Peran program pemberdayaan perempuan kepala keluarga (Pekka) terhadap peningkatan pendapatan di desa Sukarara kecamatan Jonggat kabupaten Lombok Tengah. Jurnal Agribisnis Unram, 1(1), 1-12.

Zulminarni, N., \& Fox, J. (2019). Membangun Gerakan Untuk Akuntabilitas : Belajar dari Pengorganisasian Perempuan Indonesia (1st ed.). Seknas Pekka. 